\title{
PENGEMBANGAN BAHAN AJAR EVALUASI PEMBELAJARAN UNTUK PENDIDIKAN GURU SEKOLAH DASAR UNIVERSITAS KUNINGAN
}

\author{
Heru Purnomo, Isnaini Wulandari \\ heru.purnomo@uniku.ac.id, Isnaini.wulandari@uniku.ac.id \\ Pendidikan Guru Sekolah Dasar, Fakultas Keguruan dan Ilmu Pendidikan, \\ Universitas Kuningan, Indonesia
}

\begin{abstract}
Learning Evaluation is one of the compulsory subjects that must be taken by students at PGSD FKIP Kuningan University in order to obtain assessment and evaluation skills. However, there is no teaching evaluation material for PGSD that explicitly discusses the elementary school learning evaluation process. The purpose of this study is to develop instructional evaluation teaching materials on PGSD learning evaluation courses which are expected to equip students to be applied in primary schools when they become teachers. This research method is a research and development study by taking the object of research at the Kuningan University PGSD students (UNIKU). The results of the validation of learning evaluation material experts obtained results with a total score of 74 of the 20 learning indicators assessed with a range of scores $1-5$ for the assessment of development products, so that a score of 3.7 from all assessment indicators in the learning evaluation instrument can be said with GOOD category. The results of student responses to the feasibility of developing teaching materials obtained by $90.27 \%$ of students on the response Very good and good. Based on the results obtained from the response to the readability of the product development, it was obtained that the response of students was $93.65 \%$ in the Very Good and Good categories. Based on the categorization of the gain score analysis in the Hake calculation table, the value of 0.59 is categorized as Medium. Then it can be concluded that the Learning evaluation teaching materials for Kuningan University PGSD students can be declared eligible for use.
\end{abstract}

Keywords: evaluation of learning, teaching materials, primary teacher education

\section{ABSTRAK}

Evaluasi Pembelajaran adalah salah satu mata kuliah wajib yang harus diambil oleh mahasiswa di PGSD FKIP Universitas Kuningan guna mendapatkan keterampilan penilaian dan evaluasi.Namun belum terdapat bahan ajar evaluasi pembelajaran untuk PGSD yang secara eksplisit membahas tentang proses evaluasi pembelajaran Sekolah Dasar. Tujuan penelitian ini adalah untuk mengembangkan bahan ajar evaluasi pembelajaran pada mata kuliah evaluasi pembelajaran PGSD yang diharapkan dapat membekali para mahasiswa untuk diaplikasikan di sekolah dasar ketika sudah menjadi guru. Metode penelitian ini merupakan penelitian pengembangan atau research and development dengan mengambil objek penelitian mahasiswa PGSD Universitas Kuningan (UNIKU). Hasil validasi ahli materi evaluasi pembelajaran didapatkan perolehan hasil dengan jumlah nilai 74 dari 20 indikator pembelajaran yang dinilai dengan rentang skor 1-5 untuk penilaian produk pengembangan, sehingga diperoleh nilai dengan rata-rata 3,7 dari seluruh penilaian indikator pada instrument evaluasi pembelajaran dapat dikatakan dengan kategori BAIK. Hasil respon mahasiswa terhadap kelayakan pengembangan bahan ajar diperoleh 90,27\% peserta didik pada respon Sangat baik dan baik. Berdasarkan hasil yang diperoleh dari respon keterbacaan produk pengembangan diperoleh hasil respon mahasiswa sebesar 93,65\% pada kategori Sangat Baik dan Baik. Berdasarkan pengkategorian hasil analisis gain score pada tabel perhitungan Hake maka nilai 0,59 di kategorikan Sedang. Maka dapat disimpulkan bahwa bahan ajar evaluasi Pembelajaran untuk mahasiswa PGSD Universitas Kuningan dapat dinyatakan layak untuk digunakan.

Kata Kunci: bahan ajar, evaluasi pembelajaran, pendidikan guru sekolah dasar

\begin{tabular}{|c|c|c|}
\hline Submitted & Accepted & Published \\
\hline 30 September 2019 & 21 Oktober 2019 & 12 November 2019 \\
\hline
\end{tabular}

\begin{tabular}{|l|c|c|}
\hline Citation & $:$ & $\begin{array}{r}\text { Purnomo, H., \& Wulandari, I. (2019). Pengembangan Bahan Ajar Evaluasi Pembelajaran untuk Pendidikan Guru Sekolah } \\
\text { Dasar Universitas Kuningan. Jurnal PAJAR (Pendidikan dan Pengajaran), 3(6), 1204-1215. DOI : } \\
\text { http://dx.doi.org/10.33578/pjr.v3i6.7878. }\end{array}$ \\
\hline
\end{tabular}

\section{PENDAHULUAN}

Perguruan tinggi adalah salah satu lembaga formal dalam penguasaan hardskill dalam mengembangkan kemampuan diri mahasiswa ketingkat yang lebih siap, sesuai dengan bakat, minat dan potensi yang dimiliki oleh mahasiswa itu sendiri, dimana pembelajaran 
di perguruan tinggi memberikan gambaran yang jelas tentang hasil kompetensi yang akan dicapai sesuai dengan bidang kompetensi penguasaanya.Perguruantinggi yang berkualitas juga akan dapat mencetak pemimpin dan pemikir suatu bangsa yang menentukan pembangunan negaranya di masa depan (Nulhaqim, et., al, 2016), Program studi PGSD adalah salah satu penjurusan pada Fakultas Keguruan Dan Ilmu Pendidikan, Universitas Kuningan, untuk mewadahi pendidikan yang lebih spesifik dalam penguasaan kompetensi pendidikan keguruan, khususnya bagi para calon guru sekolah dasar.

Evaluasi pembelajaraan adalah mata kuliah wajib prasyarat yang harus ditempuh oleh mahasiswa pada semester $\mathrm{V}$ di pendidikan guru sekolah dasar Universitas Kuningan. Mata kuliah evaluasi pembelajaran diharapkan dapat membekali mahasiswa tentang proses evaluasi pembelajaran di SD secara menyeluruh didalam kelas serta karakteristik sekolah dasar yang khas. Untuk mempermudah penyampaian materi evaluasi pembelajaran dibutuhkan bahan ajar yang tepat.B ahan ajar perlu dikembangkan oleh dosen guna menunjang pencapaian kompetensi peserta didik (Devi, et. al, 2009).

Ketersediaan bahan ajar evaluasi pembelajaran SD yang diperuntukan untuk

\section{KAJIAN TEORETIS \\ Bahan Ajar}

Bahan ajar merupakan satu kesatuan dari berbagai komponen yang ada di dalam penyusunan materi pembelajaran, sehingga perlunya sebuah susunan bahan ajar yang sesuai dengan standar yang jelas. Seperti yang disampaikan oleh Prastowo (2014), bahan ajar tersusun atas sejumlah komponen yaitu judul, petunjuk belajar, kompetensi dasar atau materi pokok, informasi pendukung, latihan, tugas atau langkah kerja, dan penilaian. Secara lebih lanjut Kunandar (2013) mengemukakan bahwa karakteristik bahan ajar/ materi pembelajaran terdiri dari:

a. Menggembangkan keseimbangan antara pengembangan sikap spiritual dan sosial, rasa ingin tahu, kreativitas, kerja sama dengan kemampuan intelektual dan psikomotorik. mahasiswa PGSD masih sangat terbatas dalam konteks isi bahan ajar evaluasi pembelajaran SD. Keterbatasan yang ada pada bahan ajar sekarang ini, seperti kajian evaluasi pembelajaran yang bersifat umum, padahal kebutuhan materi kuliah evaluasi pembelajaran lebih berdasarkan pada konsep-konsep dan aplikasi materi yang merujuk pada pembelajaran di sekolah dasar, seharusnya bahan ajar yang digunakan di jurusan PGSD lebih merujuk pada evaluasi pembelajaran yang dilakukan di sekolah dasar seperti evaluasi pembelajaran yang sesuai dengan proses pembelajaran disekolah dasar sesuai dengan kemampuan knowledge, skill dan attidude peserta didik di sekolah dasar, sehingga bisa membekali mahasiswa sebagai calon guru sekolah dasar untuk dapat digunakan dan diaplikasikan langsung di sekolah dasar kelak ketika mereka sudah mengajar di sekolah dasar.

Berdasarkan need analisis di atas, maka penelitian ini lebih difokuskan pada pengembangan bahan ajar evaluasi pembelajaran untuk pendidikan guru sekolah dasar sebagai wujud pengembangan bahan ajar yang digunakan di perguruan tinggi khususnya pendidikan guru sekolah dasar Universitas Kuningan.

b. Sekolah merupakan bagian dari masyarakat yang memberikan pengalaman terencana dimana peserta didik menerapkan apa yang dipelajari di sekolah kemasyarakat dan manfaat pada masyarakat sebagai sumber belajar.

c. Menggembangkan sikap, pengetahuan dan keterampilan serta menerapkan dalam berbagai situasi di sekolah dan masyarakat.

d. Memberikan waktu yang cukup leluasa untuk menggembangkan berbagai sikap, pengetahuan dan keterampilan.

e. Kompetensi dinyatakan dalam kompetensi inti kelas yang dirinci lebih lanjut dalam kompetensi dasar mata pelajaran.

f. Kompetensi inti kelas menjadi unsur pengorganisasian (organizing element) kompetensi dasar, semua kompetensi dasar dan 
proses pembelajaran dikembangkan untuk mencapai kompetensi yang dinyatakan dalam kompetensi inti.

g. Kompetensi dasar dikembangkan berdasarkan pada prinsip akumulatif, saling memperkuat (reinforced) dan memperkaya (enriched) antar mata pelajaran dan jenjang pendidikan (organisasi horizontal dan vertikal).

Dijelaskan menurut Tomlinson, B. (1998), dalam pengembangan bahan ajar dapat dilakukan dengan mengikuti enam tahapan yaitu: 1)Identification of need for material, 2) exploration of need, 3) contextual realisationof material, 4) pedagogical realisation of materials, 5) production of material andstudent use of materials and 6) evaluation of material against agrees objective.

\section{Evaluasi Pembelajaran}

Evaluasi pembelajaran menurut Ratnawulan dan Rusdiana (2015) merupakan proses pengukuran dan penilaian terhadap beberapa kemampuan siswa dalam pembelajaran, seperti pengetahuan, sikap, dan keterampilannya untuk membuat keputusan tentang kemampuan siswa. Evaluasi memiliki banyak fungsi, fungsi lain dari evaluasi pembelajaran menurut Yarmohamadian dalam Sarjadi (2013) mengemukakan bahwa indicated main evaluation functions as following: determine, review of curriculum, compare, predicate, and realization. Sedangkan menurut Jahanian (2012) mengemukakan bahwa educational evaluation has numerous functions and application, as follows: diagnose, ayllabus revision, comparison, and need analysis. Oleh karena itu dapat dikatakan bahwa evaluasi pembelajaran adalah suatu proses atau alat yang digunakan dalam proses pembelajaran yang berguna untuk mengetahui dan menentukan sejauh mana perkembangan penguasaan peserta didik dalam memahami materi yang telah dipaparkan.

Dalam setiap kegiatan evaluasi, langkah pertama yang harus diperhatikan adalah tujuan evaluasi. Penentuan tujuan evaluasi sangat bergantung pada jenis evaluasi yang digunakan. Berikut ini beberapa penjelasan mengenai tujuan evaluasi pembelajaran yaitu:

\section{Keeping Track}

Chittenden (1994) dalam Arifin (2016: 15) mengemukakan bahwa keeping track, digunakan untuk menelusuri dan melacak proses belajar peserta didik sesuai dengan rencana pelaksanaan pembelajaran yang telah ditetapkan. Untuk itu, guru harus mengumpulkan data dan informasi dalam kurun waktu tertentu melalui berbagai jenis dan teknik penilaian untuk memperoleh gambaran tentang pencapaian kemajuan peserta didik.

\section{Checking-up}

Tujuan evaluasi pembelajaran yang selanjutnya yaitu, checking-up, seorang pendidik mengecek kemampuan peserta didiknya selama mengikuti proses pembelajaran. Dengan kata lain, guru perlu melakukan penilaian untuk mengetahui bagaimana dari materi yang sudah dikuasai peserta didik dan bagian mana dari materi yang belum dikuasai.

\section{Finding-out}

Tujuan evaluasi pembelajaran memliki tujuan untuk mencari atau menemukan kekurangan peserta didik dalam proses pembelajaran. Menurut Chittenden (1994) dalam Arifin (2016) finding-out, yaitu untuk mencari, menemukan dan mendeteksi kekurangan, kesalahan, atau kelemahan peserta didik dalam proses pembelajaran sehingga guru dapat dengan cepat mencari alternatif solusinya.

\section{Summing-up}

Evaluasi juga bertujuan untuk menyimpulkan tingkat penguasaan peserta didik dalam kompetensi yang telah ditetapkan. Menurut Chittenden (1994) dalam Arifin (2016) summing$u p$, yaitu untuk menyimpulkan tingkat penguasaan peserta didik terhadap kompetensi yang telah ditetapkan. Hasil penyimpulan ini dapat digunakan guru untuk menyusun laporan kemajuan belajar ke berbagai pihak yang berkepentingan. 


\section{METODE PENELITIAN}

Penelitian yang dilaksanakan ini, merupakan penelitian pengembangan atau research and development dengan langkah yang

sesuai dengan Borg \& Gall (1983) seperti yang tersaji pada gambar 1 berikut:



Gambar 1. Langkah-langkah Research and Development

\section{Prosedur Pengembangan}

Penelitian ini merancang dan memodifikasi model pengembangan ke dalam 9 tahap dari 10 tahapan yang dikemukakan oleh Borg \& Gall. Pada tahap desiminasi tidak dilakukan secara luar karena keterbatasan waktu dan biaya dari peneliti.

1. Studi Pendahuluan

Pada tahap ini mengumpulkan berbagai informasi awal melalui wawancara dengan dosen mata kuliah Evaluasi Pembelajaran di Prodi PGSD Universitas Kuningan.

2. Perencanaan (Planning)

Tahap perencanaan difokuskan dalam mengumpulkan bahan-bahan atau referensi untuk digunakan dalam merumuskan dan menggembangkan bahan ajar

3. Pengembangan produk awal

Tahap pengembangan ini mengembangkan produk sekolah dasar diawali dengan melihat RPS, kemudian mengumpulkan dan menelaah refrensi yang diperlukan agar hasil pengembangan dapat memfasilitasi tujuan yang diharapkan ketercapaian RPS.

4. Uji coba awal

Kegiatan ini melakukan uji coba awal agar bisa melihat beberapa kelemahan-kelemahan yang ada pada produk yang dikembangkan yaitu dengan melakukan uji coba produk pada evaluasi di sekolah dasar.

5. Revisi untuk menyusun produk utama

Pada tahap ini akan dilakukan revisi dan penyempurnaan dari hasil uji dan dari masukan-masukan yang didapatkan dari ahli.

6. Uji coba lapangan (main field testing)

Uji coba lapangan dilakukan dengan menguji cobakan produk yang telah dikembangkan dan di sempurnakan pada skala yang lebih besar dibandingkan dengan uji coba awal, uji coba lapangan ini dilakukan dengan menguji cobakan bahan ajar secara terbatas pada 1 kelas di Prodi PGSD Universitas Kuningan.

7. Revisi untuk menyempurnakan produk hasil uji coba lapangan (oprational producttesting).

Kegiatan ini dilakukan setelah adanya penilaian selama kegiatan proses perkuliahan mengunakan produk yang dikembangkan dan hasil diskusi serta wawancara dengan ahli yang dilakukan pada uji coba lapangan yang pertama.

8. Uji pelaksanaan lapangan (Operational field testing)

Uji pelaksanaan lapangan melibatkan mahasiswa di 2 kelas Prodi PGSD Universitas 
Kuningan yaitu kelas $\mathrm{B}$ dan $\mathrm{C}$ dengan melibatkan seluruh mahasiswa.

9. Revisi produk final (final product rivision)

Pada tahapan ini yaitu kegiatan revisi dan menyempurnakan produk akhir setelah dilakukan revisi pada uji pelaksana sehingga diperoleh produk final yang dirasa layak untuk digunakan oleh mahasiswa sesuai dengan kebutuhan mahasiswa yang sesuai dengan RPS yang digunakan.

\section{Desain Uji Coba Produk \\ 1. Desain Uji Coba}

Uji coba dilakukan untuk mengetahui kelayakan dan efektifitas bahan ajar Evaluasi Pembelajaran sekolah dasar di PGSD Universitas Kuningan.

a. Uji ahli (expert judgment)

Sebelum produk diujicobakan, produk yang dikembangkan harus divalidasi oleh ahli penilai dibidangnya agar produk ini mempunyai jaminan layak untuk diuji cobakan kepada subjek uji coba.

b. Uji coba terbatas

Uji coba terbatas dilakukan di satu kelas di Prodi PGSD Universitas Kuningan, hasil data tersebut kemudian dianalisis dan dilakukan revisi untuk uji coba lapangan.

c. Uji coba produk lapangan

Pada perlakuan uji coba lapangan oprasional ini dilakukan seluruh mahasiswa di kelas B dan C di PGSD Universitas Kuningan. Selanjutnya hasil data tersebut dianalisis untuk menyusun produk final.

\section{Subjek Coba}

Subjek penelitian tahap pertama pada uji coba perorangan dilibatkan 1 ahli materi evaluasi Pembelajaran sekolah dasar.

\section{Teknik dan Instrumen Pengumpulan Data}

Teknik pengumpulan untuk mendapatkan data yang benar-benar valid. Ada berbagai teknik pengumpulan data yang digunakan dalam penelitian ini adalah dalam bentuk tes dan non-tes yang berupa wawancara, angket dan validasi para pakar atau ahli untuk mengukur tingkat kelayakan bahan ajar evaluasi pembelajaran sekolah dasar sesuai dengan kebutuhanya.

\section{Teknik Analisis Data}

Adapun analisis data perhitungan penelitian sebagai berikut:

a. Analisis kelayakan atau hasil validasi ahli. Data yang diperoleh berdasarkan kuisioner dianalisis mengunakan teknik statistik deskriptif berdasarkan masing-masing variabel. Untuk kebutuhan analisis kuantitatif, maka jawaban yang diperoleh diberi skor dengan kreteria sebagai berikut: 1) Skor 5 diberi kreteria Sangat baik; 2) Skor 4 diberi kreteria Baik; 3) Skor 3 diberi kreteria Cukup; 4) Skor 2 diberi kreteria Kurang baik; 5) Skor 1 diberi kreteria Sangat tidak baik

b. Analisis keefektifan

Teknik analisis data untuk mengetahui efektifitas produk pengembangan dengan pretest dan post-tes. Langkah-langkah perhitungan yang dilakukan adalah sebagai berikut.

1) Gain ternormalisasi dihitung mengacu pada persamaan Hake (1998:3) yaitu. <g> Keterangan: $\langle\mathrm{g}\rangle=$ Gain ternormalisasi Sf $=$ Skor post-test $\mathrm{Si}=$ Skor pre-test.

2) Gain ternormalisasi dijumlahkan untuk semua mahasiswa dan ditentukan rataratanya.

3) Kategori efektifitas pengembangan produk bahan ajar dan penilaian otentik mata kuliah evaluasi pembelajaran menggunakan klasifikasi Hake (1998: 3) dapat dilihat pada tabel berikut.

Tabel 1. Efektivitas Produk Pengembangan

\begin{tabular}{|c|l|c|}
\hline No & \multicolumn{1}{|c|}{ Gain } & Kategori \\
\hline 1 & $\mathrm{~g} \geq 0,7$ & Tinggi \\
\hline 2 & $0,7>\mathrm{g} \geq 0,3$ & Sedang \\
\hline 3 & $\mathrm{~g}<0,3$ & Rendah \\
\hline
\end{tabular}




\section{HASIL DAN PEMBAHASAN}

\section{Hasil Pengembangan Produk Awal}

Berikut ini disajikan data hasil pengembangan produk bahan ajar Evaluasi pembelajaran untuk pendidikan guru sekolah dasar pada mahasiswa jurusan PGSD tingkat dua, Fakultas keguruan dan Ilmu pendidikan Universitas Kuningan, ada pun tahap yang dilakukan meliputi beberapa tahap pengembangan awal sebagai berikut.

1. Studi Pendahuluan

Studi pendahuluan dilakukan peneliti dengan menganalisis rencana pembelajaran semester (RPS) yang digunakan dosen pengampu mata kuliah untuk melihat indikator capaian pembelajaran pada pembelajaran yang dilakukan setiap minggu selama satu semester penuh, dengan 14 kali pertemuan yang dilakukan dengan 12 kali pertemuan tatap muka dan 2 kali pertemuan yang dilakukan dosen pengampu secara e-learning.

\section{Perencanaan (Planning)}

Tahap perencanaan dilakukan peneliti dengan menyusun rancangan (draf) bahan ajar evaluasi pembelajaran sesuai RPS yang digunakan dalam perkuliahan evaluasi pembelajaran dan mengembangkan materi setiap sub bab yang digunakan sesuai dengan kebutuhan materi evaluasi pembelajaran pendidikan guru sekolah dasar.

3. Pengembangan produk awal

Pada tahap pengembangan produk awal peneliti menetapkan draft dan format baku bahan ajar meliputi desaian cover bahan ajar, daftar isi, materi yang disajikan pada setiap sub bab evaluasi pembelajaran yang meliputi 11 sub bab materi Evaluasi pembelajaransesuai dengan RPS yang digunakan dengan mengklasifikasikan setiap materinya kedalam setiap sub babmateri dan menyusun daftar pustaka yang digunakan.Produk awal yang sudah dikembangkan kemudian divalidasi oleh ahli Evaluasi Pembelajaran. Hasildata validasi produk pengembangan ini merupakan penilaian ahli evaluasi pembelajaran sesuai dengan muatan materi PGSD, baik dari segi layout bahan ajar, isi bahan ajar secara keseluruhan maupun sumber yang digunakan dalam menyusun bahan ajar yang dikembangkan. Data hasil validasi instrument penilaian materi Evaluasi pembelajaran yang dilakukan pada bulan April 2019. Berdasarkan Hasil validasi ahli materi evaluasi pembelajarandidapatkan perolehan hasil dengan jumlah nilai 74 dari 20 indikator pembelajaran yang dinilai dengan rentang skor 1-5 untuk penilaian produk pengembangan, sehingga diperoleh nilai dengan rata-rata 3,7 dari seluruh penilaian indikator pada instrument evaluasi pembelajaran, Berdasarkan kreteria nilai yang didapat dengan Rata-rata 3,7 maka produk pengembangan berdasarkan ahli materi evaluasi pembelajaran dengan kategori baik. Dengan demikian produk hasil pengembangan layak untuk didesiminasikan dan diujicobakan secara luas di kelas pada mata kuliah evaluasi pembelajaran dengan catatatan layak dengan revisi yang disampaikan oleh validator.

\section{Hasil Uji Coba Produk}

Hasil data yang diperoleh dari uji coba terbatas yang dilakukan di kelas A dengan jumlah mahasiswa 37 sedangkan uji pelaksanaan lapangan dilakukan dengan melibatkan 2 kelas mata kuliah evaluasi pembelajaran yaitu kelas B dan $\mathrm{C}$ dengan 63 mahasiswa yang dilaksanakan pada bulan Juni- Juli 2019

\section{Hasil Uji Coba Terbatas}

Uji coba terbatas ini dilakukan pada seluruh mahasiswa kelas A tingkat 2 jurusan PGSD Universitas Kuningan dengan subjek penelitian sebanyak 37 mahasiswa. Uji coba terbatas ini dilaksanakan dengan membagikan produk yang dikembangkan kepada semua mahasiswa dipandu oleh dosen pengampu mata kuliah evaluasi pembelajaran didampingi oleh peneliti dan anggota peneliti untuk melaksanakan kegiatan proses menggunakan produk pengembangan bahan ajar mata kuliah evaluasi pembelajaran sesuai dengan RPS yang dikembangkan oleh dosen mata kuliah. Peneliti dengan seksama mengamati selama proses pembelajaran dengan produk yang dikembangkan serta melakukan observasi apa yang dilakukan oleh mahasiswa selama menggunakan produk yang dikembangkan.

Hasil respon mahasiswa pada uji lapangan di kelas A terbatas terhadap kelayakan 
produk pengembangan bahan ajar evaluasi pembelajaran pada kelas uji coba terbatas di kelas A. Berikut ini pemaparan hasil respon mahasiswa yang memberikan respon sangat baik sebesar $51.17 \%$, respon peserta didik pada kategori baik dengan presentase paling besar dengan $39.10 \%$, respon peserta didik yang diberikan pada kategori cukup baik dengan presentase $9.37 \%$, sedangkan untuk respon kurang dengan presentasi $0.36 \%$ dan kurang sekali yaitu $0.00 \%$. Berdasarkan hasil yang diperoleh dari respon peserta didik tersebut didapatkan hasil respon yang positif terhadap kelayakan pengembangan bahan ajar, dimana kreteria penilaian yang positif pada respon kelayakan bahan ajar yang diberikan oleh mahasiswa adalah $90.27 \%$ peserta didik pada respon sangat baik dan baik. Data respon mahasiswa kelas A terhadap kelayakan produk dapat disajikan dalam bentuk diagram pada gambar berikut.

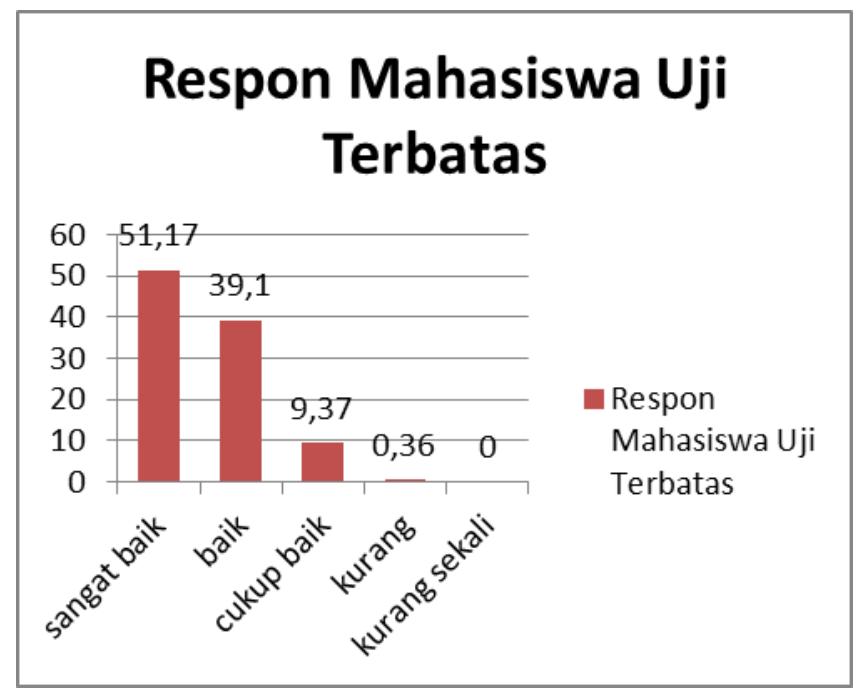

Gambar 2. Diagram Hasil Mahasiswa pada Uji Coba Terbatas

\section{Hasil Uji Pelaksanaan Lapangan.}

Hasil uji lapangan ini diambil dari seluruh mahasiswa di 2 kelas tingkat 2 jurusan PGSD Universitas Kuningan yaitu kelas B dan C dengan Jumlah 63 Mahasiswa. Sebelum uji pelaksanaan lapangan dilaksanakan dengan menggunakan produk pengembangan, peneliti melakukan penggambilan data pre-tes untuk melihat kemampuan awal mahasiswa sebelum menggunakan produk yang dikembangkan.

Setelah pengambilan data pretes, selanjutnya dalam uji pelaksanaan lapangan adalah membagikan produk pengembangan bahan ajar evaluasi pembelajaran yang telah di revisi pada uji coba terbatas kepada 37 mahasiswa di kelas A peserta untuk digunakan selama proses pembelajaran.Pada kegiatan akhir peneliti mengambil data post-tes dengan membagikan soal dengan kisi-kisi sama dengan soal pre-test untuk mengukur efektifitas kemampuan mahasiswa setelah menggunakan produk pengembangan bahan ajar. Adapun hasil data selama proses pembelajaran selama uji pelaksanaan lapangan adalah sebagai berikut.

\section{a. Data Hasil Pre-test dan Post-test}

Hasil Pre-tes dan Post-test yang didapatkan selama uji pelaksanaan lapangan pada tabel sebagai berikut. 


\begin{tabular}{|c|c|c|c|c|c|}
\hline \multirow[t]{2}{*}{ NO } & \multirow{2}{*}{ KETERANGAN } & \multicolumn{2}{|c|}{ NILAI } & \multirow{2}{*}{ INDEKS GAIN } & \multirow{2}{*}{ KRETERIA } \\
\hline & & PRE TEST & POST TEST & & \\
\hline 1 & TOTAL & 3910 & 7506.3 & 0.59 & SEDANG \\
\hline 2 & RATA-RATA & 39.10 & 75.06 & & \\
\hline 3 & NILAI TERTINGGI & 67 & 88.5 & & \\
\hline 4 & NILAI TERENDAH & 12 & 56.2 & & \\
\hline
\end{tabular}

Untuk lebih hasil pretes dan posttest uji pelaksanaan lapangan disajikan dalam bentuk diagram pada gambar 3 sebagai berikut.

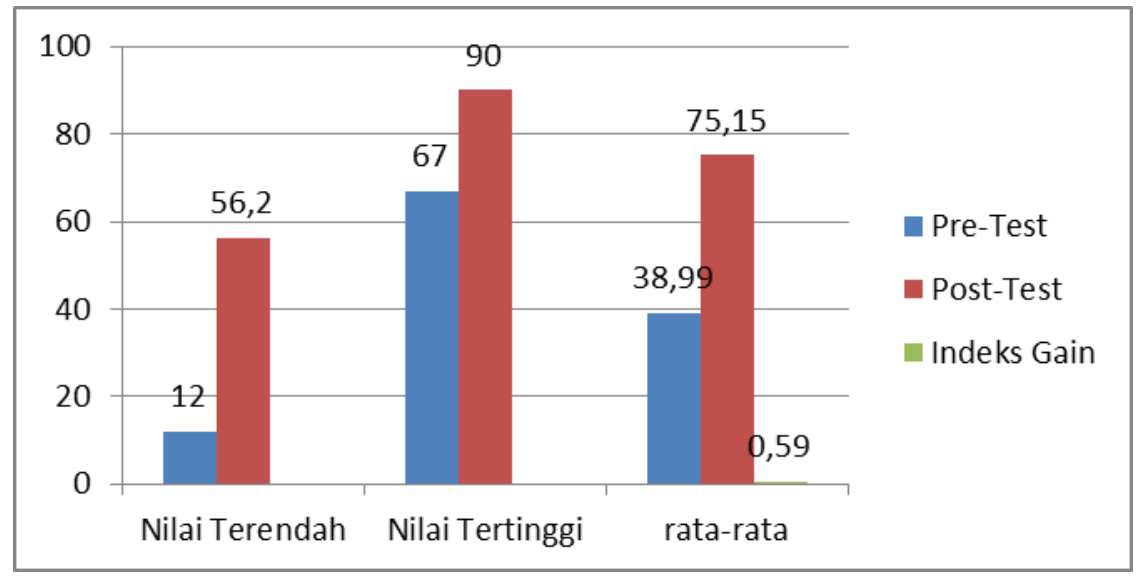

Gambar 3. Diagram pretes dan posttest

\section{a. Hasil Angket Respon Mahasiswa pada Uji Coba Lapangan}

Hasil angket respon mahasiswa uji pelaksanaan lapangan ini diambil pada seluruh mahasiswa di 2 kelas tingkat 2 jurusan PGSD Universitas Kuningan yaitu kelas B dan C dengan subjek 63 mahasiswa. Hasil respon peserta didik diperoleh hasil dengan rata-rata respon mahasiswa yang memberikan respon sangat baik sebesar $43.81 \%$, respon peserta didik pada kategori Baik dengan presentase rata-rata $49.84 \%$, untuk respon peserta didik yang diberikan pada kategori cukup baik dengan presentase $6.14 \%$, sedangkan untuk respon peserta didik dengan kategori Kurang sebesar $0.21 \%$ dan kurang sekali sebesar $0 \%$. Berdasarkan hasil yang diperoleh dari respon peserta didik di atas pada keterbacaan produk pengembangan didapatkan hasil respon mahasiswa yang positif karena kreteria respon yang positif lebih dari cukup baik pada respon mahasiswa sebesar 93.65 pada respon sangat baik dan baik. Untuk lebih jelaskan dapat disajikan dalam bentuk diagram pada gambar berikut. 


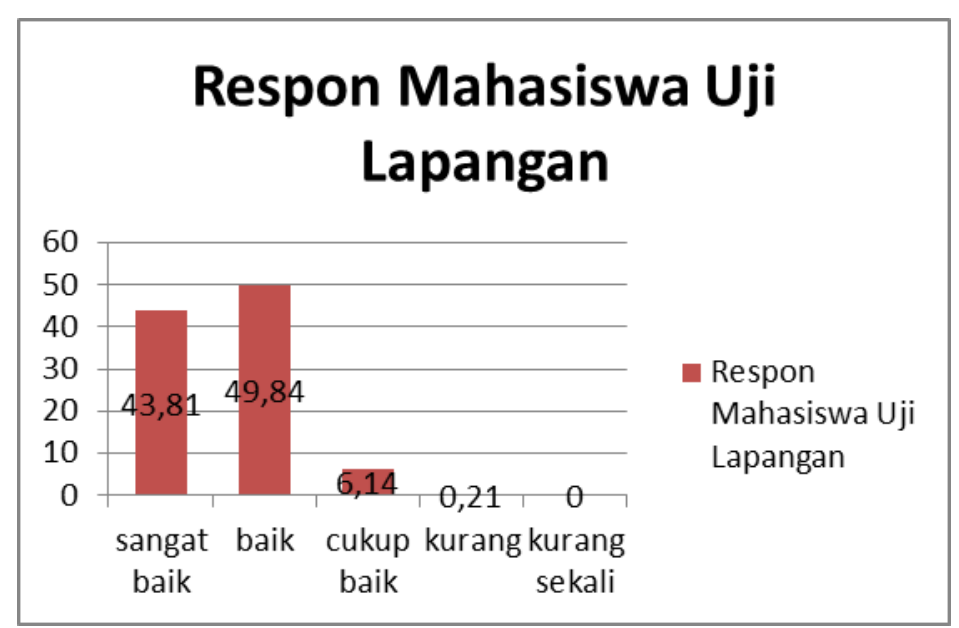

Gambar 4. Diagram Respon Mahasiswa pada Uji Pelaksanaan Lapangan Kelas A dan B

\section{Revisi Produk}

Revisi produk pengembangan dilakukan berdasarkan masukan dan saran dari para ahli materi evaluasi serta respon mahasiswa. Pada penelitian pengembangan ini, revisi dilakukan sebanyak tiga kali yaitu revisi pertama dilakukan pada saat uji awal oleh ahli materi evaluasi pembelajaran untuk mendapatkan produk yang layak di uji cobakan di lapangan, revisi yang kedua dilakukan pada saat uji lapangan secara terbatas di kelas Amahasiswa jurusan PGSD tingkat 2 Universitas Kuningan, dan uji yang terakhir atau uji yang ketiga dilakukan pada saat uji pelaksanaan lapangan di kelas $\mathrm{B}$ dan Cmahasiswa jurusan PGSD tingkat 2 Universitas Kuningan.

\section{Revisi produk pertama}

Revisi tahap pertama ini didapatkan dari hasil uji coba awal pada saat validasi produk ahli materi Evaluasi pembelajaran dengan validator Yayan Suryana, M. Pd Jabatan Fungsional Lektor, Dosen Kordinator Pengampu Mata Kuliah Evaluasi Pembelajaran Fakultas Keguruan dan Ilmu Pendidikan. Hasil validasi ini berupa penilaian, masukan perbaikan, saran dan kritik produk pengembangan bahan ajar evaluasi pembelajaran. Revisi produk awal yang di lakukan menjadi dasar untuk menggembangkan poduk yang layak untuk diujicobakan di lapangan. Adapun masukan validator ahli materi evaluasi pembelajaran guna perbaikan-perbaikan pada produk pengembangan bahan ajar adalah sebagai berikut.

a) Perbaikan pada materi khususnya terkait dengan sitasi sumber pustaka

b) Perlunya materi evaluasi pembelajaran ke-SDan yang lebih diperdalam dalam sub bab materi yang dikembangkan.

c) Referensi yang digunakan untuk evaluasi secara umum, agar mengkaitkan sumber evaluasi ke-SD-an

d) Terdapat sumber yang dicantumkan belum dimasukan ke dalam daftar referensi

e) Sumber pustaka agar diperbarui

f) Perbaikkan tata tulis pada bahan ajar yang dikembangkan.

\section{Revisi produk kedua}

Revisi produk tahap kedua dilakukan pada saat uji coba lapangan secara terbatas yang diujicobakan pada seluruh mahasiswa kelas A tingkat dua jurusan PGSD Universitas Kuningan yang berjumlah 37 mahasiswa. Revisi produk kedua ini dilakukan berdasarkan kebutuhan mahasiswa pada bahan ajar yang dikembangkan. Berikut adalah beberapa masukan perbaikanperbaikan produk pengembangan bahan ajar evaluasi pembelajaran.

a) Dalam menyajikan materi agar diklasifikasikan agar mudah untuk dibaca dan dipahami.

b) Cover dan layout perlu direvisi agar menarik dan mudah untuk dibaca dan dipahami 
c) Masih ada beberapa penulisan belum sesuai tata bahasa, masih ditulis dengan huruf kecil, mohon dikoreksi.

d) Contoh-contoh soal pada beberapa sub bab agar lebih dipertajam dan diperbanyak sebagai latihan mahasiswa.

e) Sumber pustaka agar diperbanyak dengan sumber-sumber terbaru

\section{Revisi produk ketiga.}

Revisi produk tahap ketiga ini dilakukan berdasarkan masukan, saran dan komentar produk pengembangan pada saat uji pelaksanaan lapangan secara lebih luas, yang diujicobakan pada subjek seluruh mahasiswa di 3 kelas tingkat 2 jurusan PGSD Universitas Kuningan yaitu kelas A, B dan C dengan subyek kelas A 37 mahasiswa dan kelas B dan C sebanyak 63 mahasiswa untuk menghasilkan produk final pengembangan bahan ajar evaluasi pembelajaran yang layak dan efektif.

Berikut adalah beberapa masukan produk pengembangan bahan ajar evaluasi pembelajaran pada tahap terakhir uji coba lapangan secara luas di 2 kelas dengan subjek sebanyak 63 mahasiswa.

a) Bahasa yang diguakan pada bahan ajar masih banyak mengunakan bahasa yang tidak baku, agar memperjelas bahasa yang digunakan dengan bahasa yang baku agar mudah dipahami dan menarik untuk dibaca.

b) Di bab 2 bahasa yang digunakan terlalu tinggi untuk mahasiswa, sehingga baiknya bahasa yang digunakan jangan terlalu tinggi tapi lebih sederhana dan mudah dimengerti.

c) Bahasa yang digunakan kurang ilustratif sehingga susah untuk dipahami.

d) Tolong penulisan tata tulis diperbaiki.

e) Materi dalam setiap bab sudah mewakili kebutuhan mahasiswa. Namun, apabila diperluas dengan bahasa yang menarik akan menjadi produk yang lebih baik.

f) Sumber bahan ajar perlu menambahkan sumber-sumber jurnal internasional tentang evaluasi pembelajaran di sekolah dasar

g) Bahan ajar sudah sangat baik, materi yang disajikan sudah sangat lengkap pada setiap sub bab, tapi mngkin perlu ditambahkan sumber setiap sub bab agar khasanah keilmuanya lebih beragam serta sesuai dasar-dasar evaluasi pembelajaran yang lengkap.

h) Pemberian contoh-contoh yang lebih sederhana agar lebih mudah untuk dipahami disertai dengan penjelasanya.

\section{Kajian Produk Akhir}

Terdapat beberapa tahap utama yang dilakukan peneliti dalam pengembangan materimateri pada sub-bab yang disesuaikan dengan RPS yang digunakan pada saat perkuliahan evaluasi pembelajaran, hal ini dilakukan untuk mendapatkan sebuah produk yang berkualitas sesuai dengan kebutuhan yang diharapkan untuk mendapatkan produk final yang benar-benar sesuai kebutuhan, yang pertama adalah uji coba awal dengan validasi ahli materi evaluasi pembelajaran untuk mendapatkan produk awal yang layak untuk diujicobakan di lapangan berdasarkan masukan-masukan dari kelemahankelemahan yang dimiliki produk pengembangan, yang kedua adalah mengumpulkan temuan pada uji lapangan secara terbatas pada mahasiswa di kelas A tingkat 2 jurusan PGSD Universitas Kuningan dengan subjek 37orang mahasiswa, dan yang ketiga adalah temuan pada saat uji pelaksanaan lapangan seluruh mahasiswa di 2 kelas tingkat 2 jurusan PGSD Universitas Kuningan yaitu kelas B dan C dengan subjek sejumlah 63orang mahasiswa dari beberapa tahap yang sudah dilakukan diharapkan didapatkan sebuah produk pengembangan final yang berkwalitas sesuai dengan kebutuhan mahasiswa yang dapat digunakan pada saat perkuliahan sesuai dengan RPS yang digunakan.

Pengembangan bahan ajar evaluasi pembelajaran mencoba menggembangkan sebuah bahan ajar yang layak dan efektif yang mampu memfasilitasi kebutuhan dilapangan baik dosen serta mahasiswa sesuai dengan RPS yang digunakan. Berdasarkan hasil penilaian yang diperoleh dari ahli materi evaluasi pembelajaran didaptkan hasil dengan jumlah nilai 74 dari 20 indikator pembelajaran yang dinilai dengan rentang skor 1-5 untuk penilaian produk pengembangan, sehingga diperoleh nilai dengan rata-rata 3.7 dari seluruh penilaian indikator pada instrument evaluasi pembelajaran, Berdasarkan kriteria nilai yang didapat dengan rata-rata 3.7 maka produk pengembangan berdasarkan ahli materi evaluasi pembelajaran dengan kategori baik. 
Berdasarkan hasil yang diperoleh dari respon mahasiswa pada uji coba terbatas pada satu kelas didapatkan hasil respon yang sangat positif terhadap kelayakan pengembangan bahan ajar, dimana kriteria penilaian yang positif pada respon kelayakan bahan ajar yang diberikan oleh mahasiswa sebesar $90.27 \%$ pada respon sangat baik dan baik. Sedangkan hasil yang diperoleh dari responmahasiswa pada uji coba lapangan luas yang dilakukan di dua kelas dengan subjek 63 mahasiswa di kelas $\mathrm{B}$ dan $\mathrm{C}$ nilai dari

\section{SIMPULAN DAN REKOMENDASI}

Berdasarkan hasil penelitian dan analisis data maka diperoleh kesimpulan dalam penelitian pengembangan ini sebagai berikut.

1. Berdasarkan hasil validasi ahli materi evaluasi pembelajaran didapatkan perolehan hasil dengan jumlah nilai 74 dari 20 indikator pembelajaran yang dinilai dengan rentang skor 1-5 untuk penilaian produk pengembangan, sehingga diperoleh nilai dengan rata-rata 3.7 dari seluruh penilaian indikator pada instrumen evaluasi pembelajaran, berdasarkan kreteria nilai yang didapat dengan rata-rata 3.7 maka produk pengembangan berdasarkan ahli materi evaluasi pembelajaran dengan kategori baik.

2. Pemaparan hasil respon mahasiswa pada uji coba terbatas diperoleh hasil dengan rata-rata yang memberikan respon sangat baik sebesar $51.17 \%$, respon peserta didik pada kategori baik dengan presentase paling besar dengan $39.10 \%$, respon peserta didik yang diberikan pada kategori cukup baik dengan presentase 9.37\%, sedangkan untuk respon kurang dengan presentasi $0.36 \%$ dan kurang sekali yaitu $0.00 \%$. Berdasarkan hasil yang diperoleh dari respon peserta didik di atas didapatkan hasil respon yang positif terhadap kelayakan pengembangan bahan ajar, kriteria penilaian yang positif pada respon kelayakan bahan ajar yang diberikan oleh mahasiswa adalah $90.27 \%$ keterbacaan produk pengembangan didapatkan hasil respon mahasiswa yang positif karena kreteria respon yang positif lebih dari cukup baik pada respon mahasiswa sebesar 93,65 pada respon sangat baik dan baik. Dari perolehan data nilai yang disajikan di atas maka kelayakan dan efektifitas bahan ajar evaluasi pembelajaran yang dikembangkan sudah memenuhi syarat kelayakan untuk diImpelementasikan pada proses pembelajaran di lapangan.

peserta didik pada respon sangat baik dan baik.

3. Hasil uji coba lapangan dengan rata-rata respon mahasiswa yang memberikan respon sangat baik sebesar $43.81 \%$, respon peserta didik pada kategori baik dengan presentase rata-rata $49.84 \%$, untuk respon peserta didik yang diberikan pada kategori cukup baik dengan presentase $6.14 \%$, sedangkan untuk respon peserta didik dengan kategori kurang sebesar $0.21 \%$ dan kurang sekali sebesar $0 \%$. Berdasarkan hasil yang diperoleh dari respon keterbacaan produk pengembangan didapatkan hasil respon mahasiswa yang positif karena kreteria respon yang positif lebih dari cukup baik pada respon mahasiswa sebesar 93.65 pada respon sangat baik dan baik

4. Berdasarkan pengkategorian hasil analisis gain score pada tabel perhitungan Hake maka nilai 0.59 dikategorikan sedang.

Saran pemanfaatan produk yang dapat peneliti sampaikan adalah sebagai berikut:

1. Produk pengembangan bahan ajar evaluasi pembelajaran dapat digunakan oleh para dosen pengajar evaluasi pembelajaran di PGSD dan mahasiswa untuk referensi tambahan dalam proses kegiatan pembelajaran.

2. Produk pengembangan bahan ajar evaluasi pembelajaran dapat digunakan sebagai referensi untuk pengembangan bahan ajar evaluasi pembelajaran di PGSD lebih lanjut. 


\section{DAFTAR PUSTAKA}

Arifin, Z. (2016). Evaluasi Pembelajaran. Bandung: PT Remaja Rosdakarya.

Borg. L, E., \& Gall, M. D. (1983) Edcational reseach (4thed). New York: Logman.

Devi, P. K., et. al. (2009). Pengembangan Perangkat Pembelajaran untuk Guru SMP. Bandung: PPPPTK IPA.

Hake, R.R. (1998). Interactive engagement vs traditional methods: A six-thousandstudent survey of mechanics test data for introductory physics. Departement of physics. American Journal of Physics, 1-26.

Jahanian, R. (2012). Educational Evaluation: Functions and Aplications in Educational Contexts. International Journal of Academic Research in Economics and Management Sciences, 1 (2), 12- 20.

Kunandar. (2013). Penilaian Autentik Penilaian Hasil Belajar Peserta Didik Berdasarkan Kurikulum 2013. Jakarta: Raja Grafindo persada
Nulhaqim, S. A., et., al. (2016). Peranan Perguruan Tinggi Dalam Meningkatkan Kualitas Pendidikan Di Indonesia Untuk Menghadapi Asean Community 201533 Studi Kasus: Universitas Indonesia, Universitas Padjadjaran, Institut Teknologi Bandung. Sosial Work Jurna, 6(2), 22- 27.

Prastowo, A. (2014). Pegembangan Bahan Ajar Tematik. Jakarta: Kencana Prenadamedia Grup.

Ratnawulan \& Rusdiana. (2015). Evaluasi Pembelajaran. Bandung: Pustaka Setia.

Sajadi, M. (2013). Formative Evaluation as Efficient Strategy for Learning Mathematics. Mathematics Education Trends and Research Journal, 1(1), 13.

Tomlinson, B. (1998). Material Development in Language Teaching. Cambridge: Cambridge University Press. 